УДК 811.111

Oksana MAKOVSKA,

Mykhailo VAKHOTSKYI,

Higher State Educational Institution of Ukraine

"Bukovinian State Medical University", Chernivtsi (Ukraine)

Оксана МАКОВСЬКА, Михайло ВАХОЦЬКИЙ,

Вищий державний навчальний заклад України

«Буковинський державний медичний університет»,

Чернівці (Україна)

oxanamakovska@yandex.ua

Маковская О., Вахоцкий М. Лингвопрагматические особенности лексики на обо-

Ключевые слова: лингвопрагматика текста, метафо- значение концепта «ужас» в романах Стивена Кинга.

ра, идиома, жанр ужаса.

\section{LINGUOPRAGMATIC PECULIARITIES OF THE LEXICAL UNITS DENOTING CONCEPT “HORROR" IN STEPHEN KING'S NOVELS}

\section{ЛІНГВОПРАГМАТИЧНІ \\ ОСОБЛИВОСТІ ЛЕКСИКИ НА \\ ПОЗНАЧЕННЯ КОНЦЕПТУ «ЖАХ» У РОМАНАХ СТIBEHA КIHГА}

\begin{abstract}
В статье рассмотрены лингвопрагматические аспекты создания эффекта ужаса в романах английского писателя Стивена Кинга. В частности, внимание сосредоточено на лингвостилистических средствах вербализации концепта «ужас». Выявлено, что автор часто прибегает к метафоре, сравнению, активно использует идиомы и фразеологические единицы. В общем, проанализированые лексические средства полностью выполняют возложенную на них функцию: обеспечивают психоэмоциональный фон произведения, способствуют правильному построению сюжета, позволяют держать читателя в напряжении и влиять на его сознание.
\end{abstract}

In Stephen King's works horrors exuberate with abandon filling the space and our imagination with absolutely negative emotions. But are they really that imaginary as we think? In fact, fear is the initial congenital feeling of each person, inherited from one's ancestors, laid genetically, the only important emotion, which sometimes destroys our psyche. Any stress during the day, illness, watching others' sufferings make us be afraid. This is reflected in dreams, experience, tendency to alcohol or drugs consumption, madness.

Stephen King's heroes are ordinary, average people facing some unfavourable events that at some stage of their lives lead to the destruction of ideals, families, friendship and thus they bring evil upon themselves. The reality is filled with mystical horror, all the fears crawl out of the subconsciousness to the surface, we are scared of what we do not understand. All the characters are carriers of a variety of the author's ideas, he experiments psychoanalysis and even some Freudian ideas upon them.

The given paper aims at describing linguopragmatic peculiarities of Stephen King's novels, the use of lexical, stylistic and idiomatic means for the verbalization of the concept "fear". Some objectives have to be singled out in the framework of this article: a) explain, what the purpose of the "horror" genre is; b) analyze the linguistic and stylistic devices used by the author in his works; c) determine the pragmatic function of the explored texts.

The relationship between the author and his characters, as well as the characters with the readers is easily traced in all the works of S. King. Linguopragmatic aspect of the study of the author's specific style is stipulated by the correct formation of the situations in which the characters are found and is mediated by the text filled with individualized and expressive language means for the direct influence upon the reader.

The notion of "form" (or "passport") of the linguistic genre was introduced into modern linguistics by T. Shmeliova. This model has the following parameters:

- communicative purpose of the genre is a background typology. The researcher isolates informative, evaluative, etiquette (performative), imperative speech genres;

- the concept of the author is based on oppositions that determine its sociolinguistic and linguopsychological status: known - unknown; senior - equal - slave; authoritative - non-authoritative; one who has the power - who has no authority; well informed - poorly informed; interested in communication - not interested in communicating etc;

- the concept of sender is based on the same parameters as the concept of receiver;

- event content: this option has the following features: relatedness / non-relatedness to the personal sphere of the sender (recipient); time-scale prospective events; its evaluation; microevents that shape the event;

- communicative factor of the past - events that led to the appearance of the genre;

- communicative factor of the future is a factor that contributes to the development of discursive events within the genre, and the prospects for the development of the genre itself;

- language embodiment parameter - linguistic presentation of the genre ${ }^{1}$; stable genre norms ${ }^{2}$.

According to A. Rati ${ }^{3}$ horror literature is inherently allegorical and symbolic because it enables us to realize what we are most afraid of, gives us a chance to feel those very emotions that are necessary personally for us, but at the same time they are redundant for the society. The essence of fear is that intuition at the level of instincts may reveal the things denied by the materialistic society. Horror is one of the paradoxical genres, because it attracts us by those elements and emotions which are disgusting and repellent in the everyday life. 
Linguistic situations presented by the author in his works aim at creating the effect of horror, despair, hopelessness, waiting for death.

For example, in "The Shining"4 family at midnight hears the elevator starts moving, but this is impossible because it is disconnected and they are in an empty hotel: Thump. The door had slid shut down there. A humming whine as the elevator began to rise. She saw the engine housing on top of the car first through the diamondshaped window, then the interior of the car, seen through the further diamond shapes made by the brass gate. Warm yellow light from the car's overhead. It was empty. The car was empty. It was empty but (on the night of the party they must have crowded in by the dozens, crowded the car way beyond its safety limit but of course it had been new then and all of them wearing masks). ${ }^{5}$

It should be noted that the investigated novels have a peculiarity: the author imposes neither some particular viewpoint nor the ideology of his characters, we may state that they do not often arouse sympathy when the inevitable happens, since they allow many things to occur; instead, the reader remains a silent observer, until the outcome ensues.

Interesting is the fact that $\mathrm{S}$. King selects horror situation for each character separately, taking into consideration his/her mental state, opportunities, and even age. For example, the fear in Danny's imagination appears as animation of the inanimate objects: in front of him the extinguisher becomes "alive"

Daddy! he tried to scream, but his closed throat would not allow a word to pass. He was on his own. Behind him the sound grew louder, the dry sliding sound of the snake, slipping swiftly over the carpet's dry hackles. At his heels now, perhaps rising up with the clear poison dribbling from its brass snout. fabulous images in the visions of the boy, in a dark room at Danny sees the severed head of a fairy tale "Bluebeard"

In the next moment the author appeals to allusions, using fabulous images in the boy's visions: in the dark hotel rooms Danny sees the severed heads from a fairy tale "Bluebeard": The old fairy tale book had depicted her discovery in ghastly, loving detail. The image was burned on Danny's mind. The severed heads of Bluebeard's seven previous wives were in the room, each one on its own pedestal, the eyes turned up to whites, the mouths unhinged and gaping in silent screams. They were somehow balanced on necks ragged from the broadsword's decapitating swing, and there was blood running down the pedestals.

To create a feeling of disgust, combined with fear and threat to life in the studied works the author makes corpses come to life and act as separate characters: He could only hammer on the door and hear the dead woman coming for him, bloated belly, dry hair, outstretched hands something that had lain slain in that tub for perhaps years, embalmed there in magic. ... when the years-damp, bloated, fish-smelling hands closed softly around his throat and he was turned implacably around to stare into that dead and purple face.

Several other hallucinations the father sees as the main character of the horror novel "The Shining" are as follows: in an empty bar he begins to see people making parties, talk to them, and later his wife finds him drunk, regardless the fact that alcoholic drinks were not there:

"Quite all right," the man in the white mess jacket said. The polite, clipped English coming from that thug's face was surreal. "A drink?" - "Martini." From behind him, another comber of laughter broke; Roger was howling to the tune of "Home on the Range." Someone was picking out accompaniment on the Steinway baby grand. - "Here you are." The frosty cold glass was pressed into his hand. Jack drank gratefully, feeling the gin hit and crumble away the first inroads of sobriety.

In the following example one can trace another allusion - referring to the historical personalities, who also can frighten and cause horror:

For a moment his rage was so great that be literally could not speak. The blood beat loudly in his ears. It was like getting a call from some twentiethcentury Medici prince ... no portraits of my family with their warts showing.

Wendy, Jack Torrance's wife, doesn't see a parallel world, has no hallucinations and, thus, in opposition "good - evil" does not act as the weak link, on the contrary, she can resist her husband's aggression, protect her son, she realizes that Jack is easily exposed to alcohol, and is unstable.

In the novel "The Shining" S. King refers to specific graphic tools for creating mysterious: occasionally the boy Danny has visions in which he sees alphabetic characters "REDRUM". But, first, the child still cannot read well, and second, playing of letters allows to assume that the author means "red room" - room full of blood. Later, closer to the denouement of the plot, the reader clearly understands: the word should be read backwards, since the boy sees it reflected in the mirror. Later it also becomes clear to the characters - Danny's parents who succeeded to read it in a proper way "MURDER".

Undoubtedly, Stephen King is a master of his craft, the terrible pictures of his works suggest a real fear, and in the pages of his novels and stories rat-eaters and giant creeping animals are born, vampires, zombies, ghosts return to life from the parallel world and penetrate the real world, sadists, murderers, maniacs actively wield around. Linguopragmatic effect is mainly achieved by the fact that it is all imposed on the fabric of real life, against the background of everyday life, human relations, regardless of their social status, place of residence, personal qualities. This very combination of worlds and emotions keeps the reader in a permanent tension.

Metaphorization is one of the most common means of enriching literary work without formation of new units. According to N.D. Arutiunova, an essential component of the mechanism of metaphor is a comparison procedure. It comes down to finding common characteristics, "metaphor can be deduced from a comparison based on parallelism of different-leveled phenomena".

Comparisons make the characters more profound and meaningful, the comparison made on the basis of physical characteristics of the characters, their appearance, changes which suddenly occur against the background of the dynamics of a particular situation, help to understand the image right, trace the basic idea suggested be the author: His face twisted and writhed as if snakes crawled beneath his skin"'.

Strung up like piano wire, he lay staring into the 
dark, knowing it might be hours yet before he could sleep. It was joined by others and they suddenly rippled all the way up his back to his medulla oblongata, playing his spine like a jungle instrument. But he didn't take the elevator back down. It was too much like an open mouth. Too much by half. He took the stairs ${ }^{10}$.

Often they are a direct indication or hint to the reader how to accept the situation or the reality of the character: Moss struck his shoulders like flabby corpse-hands ${ }^{11}$.

In the novel "The Shining" S. King compares family in an enclosed space to microbes in the guts of the monster: Inside its shell the three of them went about their early evening routine, like microbes trapped in the intestine of a monster ${ }^{12}$.

But still, the main function of tropes in the text is the intensification of reading in order to imagine the scene better and delve into the work more deeply. Demonstration of the dark and disgust requires appropriate linguistic means for the transmission of feelings of the main characters, description of features or traits of unpleasant characters or unreal, imaginary beings: Her voice, warped and distorted, cut through the babble like a dull ax through a calf's brain; he sounded like a man being drowned in a bucket of mud; "volcanoes blurted endless magma like giant pimples on some ugly adolescent's baseball head ${ }^{13}$.

The above mentioned quotes show that the use of tropes in a work of fiction has primarily pragmatic function - to perform its role only in certain context making the author's intention true. In this case it is a verbalization of the concept of horror.

Features and originality of Stephen King's artistic manner can be understood and evaluated only in those cases where the actual reader matches a text with some extra-linguistic situation. The works of the author reflect his conceptual picture of the world, based on certain biographical experiences of the author and become clear to the reader thanks to word-realities.

Stephen King's language is full of a large number of realities that clearly characterize national life, customs, culture, society, stereotypes and ideals of the Americans of the middle class beginning from the second half of the twentieth century until the early twenty-first.

Phraseological units of language play a major role in strengthening the characteristic features of the literature of any genre. Their main objective in the text may be determined as an intensification of the author's message for readers' better perception of the brighter images. The author is interested not so much at the message, but at its interpretation, and thus, uses the associative-image signs of the described notions.

In Stephen King's novels there are plenty of idioms, aphorisms and other stable expressions. Idiom is a stable, semantically opaque or metaphorical unit which has only general meaning that cannot be traced from the meaning of all its parts separately ${ }^{14}$. Phraseological units or idioms are also considered as separate language units with totally or partly redefined values.

T. Arbekova offered such definition of the idiom: "combination of words with low combining properties, which is stipulated by structural and semantic features of the components (or one of them), or a specific nature of relations between the phrase and reality, as well as the combination of two factors" $" 15$.

The idiomatic expressions of the studied texts should be analyzed to illustrate their abundance in horror novels.

When the main character of "The shining" is trying to refrain from comments, the author tells us that he had to "bite the tongue":

All my men wear English Leather or they wear nothing at all came into his mind for no reason at all, and he had to clamp his tongue between his teeth to keep in a bray of laughter ${ }^{16}$.

The embodiment of Evil hotel «Overlook» several times changed owners, that is passed from hand to hand: The Overlook has changed hands several times since World War II and it seems that each successive manager has put everything they don't want up in the attic ${ }^{17}$.

Listening to the manager Jack had to demonstrate a willingness to work and his interest, so "wore a representative smile": He looked at Jack for comment, and Jack flashed the PR smile again, large and insultingly toothy. And then disgust just "covered him with wave": Jack supposed that this fussy little man's pride was justified, and then his original dislike washed over him again in a wave.

Knowing that Danny feels her emotions, Wendy felt "more than undressed": She suddenly felt more naked than naked, as if she had been caught in an obscene act.

Stephen King fills the imagination of the characters with his own feelings, thoughts and fears and thus transmits through them some personal mental anguish and dreams, his own ideas and perceptions about the horrors of the psyche:

Monsters are real, and ghosts are real too. They live inside us, and sometimes, they win.

Alone. Yes, that's the key word, the most awful word in the English tongue. Murder doesn't hold a candle to it and hell is only a poor synonym.

The thing under my bed waiting to grab my ankle isn't real. I know that, and I also know that if I'm careful to keep my foot under the covers, it will never be able to grab my ankle.

We make up horrors to help us cope with the real ones.

Sometimes human places, create inhuman monsters.

Wendy? Darling? Light, of my life. I'm not gonna hurt ya. I'm just going to bash your brains in.

The sleep of reason breeds monsters ${ }^{18}$.

Stephen King's idiomatic expressions have become a world heritage. Arguably, his fans, connoisseurs, supporters of the genre, "made them quotes". These expressions completely perform their pragmatic function - persuasion and influence on the reader. This is a unique type of associative concepts that are verbalized by linguistic means in a very peculiar way because several fragments of human knowledge about the world are combined inside of them.

\section{References:}

${ }^{1}$ Bhatia V. K. Analysing Genre. Language Use in Professional Settings / Vijay K. Bhatia. - L. ; N. Y. : Longman, 1993. $-246 \mathrm{p}$.

${ }^{2}$ Andrianova N. Pryntsypy taksonomii virtualnykh movlennievykh zhanriv / N. Andrianova // Naukovi zapysky. - 
Vypusk 130. - Seriia: Filolohichni nauky (movoznavstvo) Kirovohrad: RVV KDPU im. V. Vynnychenka, 2014. - S. 53-57.

3 Rati A. O. Anhlomovna literatura zhakhiv: evoliutsiia zhanru / A.O. Rati // Visnyk LNU imeni Tarasa Shevchenka. - № 14 (273). - Ch. II. - 2013. - S. 64-70.

${ }^{4}$ King S. The Shining / S. King. - NY : Anchor Books, 2012. $-337 \mathrm{p}$

${ }^{5}$ Ibid., P. 145.

${ }^{6}$ Ibid., P. 148.

${ }^{7}$ Ibid., P. 152.

${ }^{8}$ Arutiunova N. D. Teoriia metafory / N.D. Arutiunova. M.: Prohress, 1990. - S. 5-32.

${ }^{9}$ King S. The Gunslinger / S. King. - (The Dark Tower, Book 1). - NY : Plume, 2003.

${ }^{10}$ King S. The Shining / S. King. - NY : Anchor Books, 2012. -337 p. - P. 53.

${ }^{11}$ King S. The Gunslinger / S. King. - (The Dark Tower, Book 1). - NY : Plume, 2003. - P. 128.

${ }^{12}$ King S. The Shining / S. King. - NY : Anchor Books, 2012. -337 p. - P. 145 .

${ }^{13}$ King S. The Gunslinger / S. King. - (The Dark Tower, Book 1). - NY : Plume, 2003. - P. 128.

14 Nehrych N.D. Poniattia "idioma" i "frazeolohichna odynytsia" - spilne ta vidminne u linhvistychnomu rozuminni / Nataliia Nehrych // Naukovi pratsi: naukovometodychnyi zhurnal. - Vyp. 207. - T. 219. Filolohiia. Movoznavstvo. - Mykolaiv : Vyd-vo ChDU im. Petra Mohyly, 2013. - S. 78-80.

15 Arbekova T.I. Leksykolohyia anhlyiskoho yazyka / T.I. Arbekova. - M.: "Vysshaia shkola", 1977. - 240 s.

${ }^{16}$ King S. The Shining / S. King. - NY : Anchor Books, 2012. $-337 \mathrm{p}$.

${ }^{17}$ King S. Night Shift / S. King. - NY : New American Library, 1979. $-326 \mathrm{p}$.

${ }^{18}$ King S. The Shining / S. King. - NY : Anchor Books, 2012. -337 p. - P. 145.

Маковська О., Вахоцький М. Лінгвопрагматичні особливості лексики на позначення концепту «жах» у романах Стівена Кінга. У статті розглянуто лінгвопрагматичні аспекти створення ефекту жаху у романах англійського письменника Стівена Кінга. Зокрема, зосереджено увагу на лінгвостилістичних засобах вербалізації концепту «жах». Виявлено, що автор часто вдається до метафори, порівняння, активно використовує ідіоми та фразеологічні одиниці. Загалом, проаналізовані лексичні засоби повністю виконують покладену на них функцію: забезпечують психоемоційне тло твору, сприяють правильній побудові сюжету, що дозволяє тримати читача у напрузі і впливати на його свідомість.

Використання художніх засобів у літературному творі має на меті насамперед показати особливий стиль самого автора, сформувати властиву лише йому картину світу. Вплетення у сюжет певних жанрово-стильових елементів робить розповідь більш інформативною, експресивною, логічною. Крім того, вони дають змогу повніше розкрити образи головних героїв та забезпечують додаткову характеристику оточуючого світу. Стилістичні засоби С. Кінга мають суб' єктивне забарвлення, тому у першу чергу пояснюють внутрішній світ самого письменника.

Прагматичний компонент висловлювання - це його властивість реалізувати певні інтенції письменника і впливати на поведінку читача. Кінцевою метою використання будь-яких лексичних засобів у художній літературі є досягнення такої реакції адресата, яка відповідає бажанням автора повідомлення. Це стає можливим завдяки використанню певних вербальних засобів впливу, однією з найважливіших рис яких $\epsilon$ їхня антропоцентрична спрямованість, яка виражається у простоті, доступності, пристосованості до швидкого сприйняття повідомлення.

Основним завданням текстів жанру хоррор є вплив на читача за допомогою вербалізації у текстах концептів «жах», «страх», формування його психоемоційного стану, задля активації первинного інстинкту кожної людини страху. Для цього автор використовує різноманітні мовні засоби: 3 метою зіставлення на основі подібності широко застосовуються порівняння і метафори, задля передачі специфічних реалій, характерних для даного стилю понять, у рамках здійснення своєрідного психоаналізу у читача $\epsilon$ доречними стійкі мовні сполуки - ідіоми, афористичні авторські висловлювання.

Ключові слова: лінгвопрагматика тексту, метафора ідіома, жанр жаху.

Маковська Оксана - викладач кафедри іноземних мов ВДНЗ України "Буковинського державний медичний університет». Автор понад 50 наукових та методичних статей. Наукові інтереси: когнітивна лінгвістика, вербалізація лексичних одиниць у галузевих терміносистемах украӥнської та англійської мов.

Makovska Oksana - lecturer of the department of Foreign Languages of Higher State Educational Establishment of Ukraine "Bukovinian State Medical University». Author of over 50 scientific and methodological articles. Research interests: cognitive linguistics, verbalization of lexical units in branch terminological systems in Ukrainian and English.

Вахоцький Михайло - старший викладач кафедри іноземних мов ВДНЗ Украӥни "Буковинського державний медичний університет». Автор 30 наукових та методичних статей, співавтор 1 посібника для іноземних студентів. Наукові інтереси: функиіонування медичних термінів з компонентом-власною назвою.

Vakhotskyi Mykhailo - senior lecture of the department of Foreign Languages of Higher State Educational Establishment of Ukraine "Bukovinian State Medical University». Author of 30 scientific and methodological articles, coauthour of 1 manual for foreign students. Research interests: functioning of medical terms with the onymic component.

Received: 04-11-2016

Advance Access Published: December 2016

C Makovska O., Vakhotskyi M., 2016 